УДК 577.1:544.77-148

\title{
СВОЙСТВА ГИДРОГЕЛЕЙ НА ОСНОВЕ СМЕСЕЙ АЛЬГИНАТА НАТРИЯ С ДРУГИМИ ПОЛИСАХАРИДАМИ ПРИРОДНОГО ПРОИСХОЖДЕНИЯ
}

\author{
() А.А. Юсова ${ }^{I}$, И.В. Гусев ${ }^{2}$, И.М. Липатова ${ }^{l *}$ \\ ${ }^{1}$ Институт химии растворов им. Г.А. Крестова РАН, ул. Академическая, 1, \\ Иваново, 153045 (Россия), e-mail: aay@isc-ras.ru \\ ${ }^{2}$ Московский государственный университет технологии и управления \\ им. К.Г. Разумовского, ул. Земляной Вал, 73, Москва, 109004 (Россия), \\ e-mail: igor.gusev.1986@mail.ru
}

\begin{abstract}
Получены формоустойчивые альгинат-кальциевые гидрогели, в которых альгинат натрия частично заменен карбоксил-содержащими полисахаридами, не обладающими собственной способностью к ионотропному гелеобразованию с ионами кальция. В качестве второго полисахарида использовали гиалуронат натрия, высокометоксилированный пектин и сукцинилированный хитозан. Обсуждены экспериментальные данные о влиянии второго полисахарида в смесях с альгинатом на степень набухания гидрогелей в воде, устойчивость к синерезису и физико-механические характеристики смешанных гидрогелей в широком диапазоне соотношений компонентов.

Ключевые слова: альгинат натрия, сукцинилированный хитозан, пектин, гиалуронат натрия, ионотропное желирование ионами кальция, физико-механические свойства смешанных гидрогелей.
\end{abstract}

\section{Введение}

Альгинат натрия - ионогенный полисахарид, получаемый путем щелочной экстракции бурых водорослей, благодаря комплексу весьма ценных в практическом отношении свойств продолжает занимать одно из ведущих мест среди водорастворимых полимеров природного происхождения. Водорастворимость, нетоксичность, высокая загущающая способность обусловливают широкое применение этого полисахарида в пищевой, косметической, текстильной, бумажной и других отраслях промышленности [1]. Неослабевающий интерес исследователей к альгинату натрия связан с его способностью формировать гидрогели в водных растворах при добавлении солей бивалентных металлов. Практическое применение нашли соли кальция, ионы которого выступают в качестве сшивающих агентов, взаимодействуя с карбоксильными группами гулуронатных блоков молекул альгината [2-5]. Высокая водоудерживающая способность, отсутствие токсичности и биодеградируемость альгинатных гидрогелей, трехмерно сшитых ионами кальция, позволяют разрабатывать на их основе новые материалы биотехнологического, фармакологического и медицинского назначения [6-8]. В частности, такие гидрогели могут быть использованы при создании систем доставки лекарств (drug delivery systems - DDS) и ранозаживляющих покрытий [7-9]. Альгинат натрия обладает комплексом биологически активных свойств (противовирусная, иммуномодулирующая, гемостатическая активность [7, 10], поэтому гидрогелевый материал на его основе оказывает комплексное действие как за счет самого гелеобразующего полимера, так и за счет лекарства, в него включенного. Спектр биологически активного действия

Юсова Анна Анатольевна - кандидат технических наук, научный сотрудник, тел.: (4932) 33-62-61, e-mail: aay@isc-ras.ru

Гусев Игорь Вячеславович - аспирант, тел.: (499) 237-11-13, e-mail: igor.gusev.1986@mail.ru Липатова Ирина Михайловна - доктор химических наук, главный научный сотрудник, тел.: (4932) 33-62-61, e-mail: aay@isc-ras.ru полимерной матрицы может быть расширен за счет использования композиционных гидрогелей на основе смесей альгината с другими биополимерами. В качестве второго полимерного компонента композитных гидрогелей на основе альгината натрия в настоящей работе выбраны биодеградируемые и неток-

\footnotetext{
* Автор, с которым следует вести переписку.
} 
сичные полисахариды: пектин, гиалуронат натрия и сукцинилированный хитозан. Каждый из использованных полисахаридов обладает собственным комплексом биологически активных свойств. Использование смесей полисахаридов позволяет получать новые материалы, в которых просуммированы свойства, присущие каждому компоненту. Частичная замена альгината натрия другим карбоксил-содержащим полисахаридом, характеризующимся существенно более низкой способностью к ионотропному желированию ионами кальция или полным отсутствием этой способности, может вызвать существенное изменение пористой структуры гидрогелей, а комплекс структурно зависимых свойств смешанных гидрогелей будет определяться их полимерным составом.

Цель настоящей работы - исследование влияния полимерного состава на физико-механические свойства и водоудерживающую способность трехмерно сшитых ионами кальция гидрогелей на основе смесей альгината натрия с другими биологически активными полисахаридами.

\section{Экспериментальная часть}

В качестве объектов исследования использовали промышленные образцы полисахаридов природного происхождения: альгинат натрия (АН), имеющий характеристическую вязкость $[\eta]=4,51$ дл/г; яблоч-

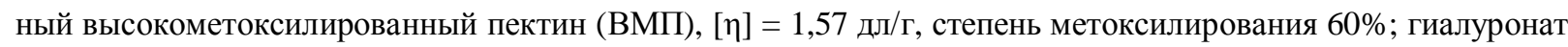
натрия $(\Gamma \mathrm{H}),[\eta]=17,75$ дл/г; сукцинилированный хитозан $(\mathrm{CX}),[\eta]=1,31$ дл/г, степень замещения 75\%.

Характеристические вязкости $[\eta]$ полисахаридов определяли экстраполяционным методом из концентрационных зависимостей приведенной вязкости. Измерения проводили на вискозиметре Уббелоде, диаметр капилляра 0,73 мм, при постоянной температуре $25^{\circ} \mathrm{C}$. В качестве фонового электролита вводили $0,1 \mathrm{M}$ раствор хлорида натрия.

Смешанные формоустойчивые гидрогели различного полимерного состава получали путем смешения в заданных объемных соотношениях предварительно приготовленных и выдержанных в течение 4 ч $2 \%$ растворов полисахаридов. Суммарная концентрация по полимерам при этом оставалась постоянной ( 2 масс. \%). В приготовленные смешанные растворы вводили навеску сульфата кальция из расчета $0,15 \%$ $(0,011$ моль/л) к массе смеси, тонко диспергированную в небольшом количестве глицерина (1\% к массе смеси) и после немедленной гомогенизации полученные суспензии выдерживали в пластиковых формах в состоянии покоя не менее 8 ч. Формоустойчивые гидрогели получали в виде дисков массой 3 г с диаметром 2,4 см, высотой 0,7 см и поверхностью $14 \mathrm{~cm}^{2}$.

Определение динамической вязкости растворов и частично сшитых гидрогелей полисахаридов проводили на ротационном вискозиметре РЕОТЕСТ 2 с рабочим узлом «цилиндр в цилиндре» при $25 \pm 0,5^{\circ} \mathrm{C}$ в диапазоне скоростей сдвига $1,5-1,3 \cdot 10^{3} \mathrm{c}^{-1}$.

Степень набухания определяли гравиметрическим методом [11] в дистиллированной воде при термостатировании $25 \pm 0,5^{\circ} \mathrm{C}$. Через фиксированные промежутки времени образцы извлекали из водной среды и после удаления остатков воды с поверхности фильтровальной бумагой осуществляли взвешивание.

Количество воды, выделяющейся при синерезисе, определяли весовым методом. Образцы выдерживали в блистерах на воздухе. Через фиксированные промежутки времени образцы промакивали фильтровальной бумагой и после удаления выделившейся воды с поверхности осуществляли взвешивание.

Физико-механические характеристики гидрогелевых дисков определяли на анализаторе текстуры CT3 Brookfield (Англия), используя пять параллельных измерений для образцов одного состава. Испытания проводились путем однократного сжимающего воздействия на испытуемый образец. Сжатие осуществлялось металлическим цилиндром с диаметром рабочей поверхности 35 мм. Скорость сжатия 1 мм/мин. Сила сжатия 1000 г. Выдержка при сжатии 10 сек. Температура $24{ }^{\circ} \mathrm{C}$.

\section{Обсуждение результатов}

В данной работе смешиваемые биополимеры относятся к водорастворимым, полужесткоцепным полисахаридам, содержащим гидроксильные и диссоциирующие в воде карбоксильные группы.

Альгинат натрия представляет собой семейство неразветвленных двойных сополимеров: остатков $\beta$-D-маннуроновой кислоты и $\alpha$-L-гулуроновой кислоты, соединенных $1 \rightarrow 4$ гликозидными связями (формула 1) [2].

Пектин - кислый растительный полисахарид, главную углеводородную цепь которого составляют 1,4-связанные остатки $\alpha$-D-галактуроновой кислоты (формула 2). Часть карбоксильных групп в макромолекулах этерифицирована метанолом. 


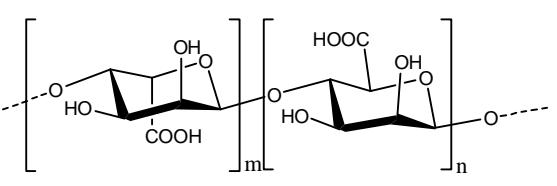

(1)

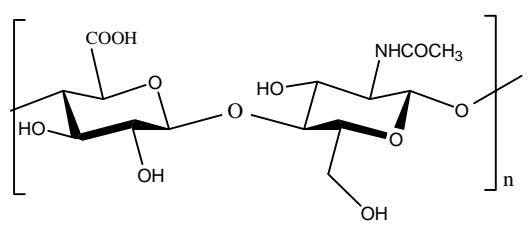

(3)

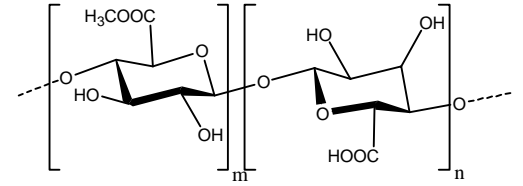

(2)

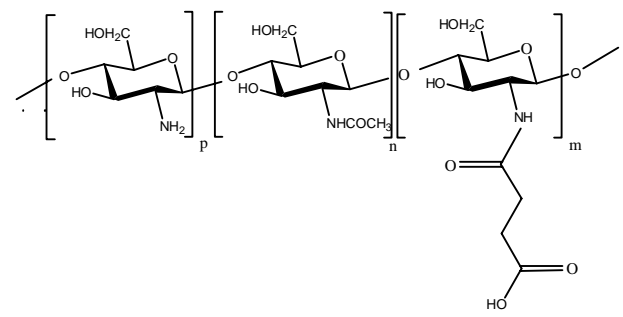

(4)

Если доля звеньев галактуроновой кислоты с метоксилированными карбоксильными группами превышает 50\%, то такой полимер относят к группе высокометоксилированных пектинов (ВМП), при более низком содержании $-\mathrm{OCH}_{3}$-групп пектины считаются низкометометоксилированными (НМП) [12]. Способность НМП образовывать с $\mathrm{Ca}^{+2}$ или другими бивалентными катионами гидрогели хорошо известна [11, 13], известна также их способность образовывать смешанные гидрогели с альгинатом натрия в присутствии ионов кальция [11]. Способность пектинов к ионному взаимодействию с бивалентными катионами быстро снижается с увеличением степени метоксилирования [15].

Гиалуронат натрия - мукополисахарид, компонент соединительной ткани млекопитающих. Его макромолекулы состоят из дисахаридных звеньев, компонентами которых являются $\mathrm{N}$-ацетил-D-глюкозамин и D-глюкуроновая кислота, связанные между собой $\beta-1 \rightarrow 4-$ и $\beta-1 \rightarrow 3$ связями (формула 3 ) [16].

Сукцинилированный хитозан представляет собой карбоксил-содержащее водорастворимое производное хитозана, получаемое по реакции $\mathrm{N}$-ацилирования путем обработки хитозана янтарным ангидридом в его уксуснокислом растворе (формула 4) [17, с. 158-160]. В результате такой модификации одна из двух карбоксильных групп янтарной кислоты становится связанной с молекулой хитозана амидной связью, а вторая остается свободной и обусловливает анионактивные свойства СХ в водном растворе. Известна способность высокозамещенного СХ в низкоконцентрированных растворах к ионной сшивке катионами кальция [18], эта способность снижается с уменьшением степени замещения.

Для получения смесей предварительно готовили $2 \%$ растворы индивидуальных полисахаридов и исследовали их реологические свойства. На рисунке 1 представлены кривые течения исходных $2 \%$ растворов полисахаридов (кривые 1-4), не содержащих ионов кальция. Кривые течения, представляющие собой зависимости эффективной вязкости от напряжения сдвига в логарифмических координатах, позволяют судить о надмолекулярной организации растворов полимеров. Чем больше ход кривых отклоняется от горизонтального положения, тем выше значение структурной составляющей вязкости (аномалия вязкости), тем значительнее характер течения раствора отличается от ньютоновского. Как следует из рисунка 1 (кривые 1-4), динамическая вязкость и степень структурированности исходных растворов полисахаридов увеличиваются с увеличением их характеристической вязкости, по величине которой можно судить о размере первичных элементов структуры. Так, раствор ГН, имеющий максимальную [ฑ́], характеризуется наибольшей динамической вязкостью и структурированностью, а растворы ВМП и СХ показали очень низкую динамическую вязкость и ньютоновский характер течения.

Представляло интерес оценить собственную способность выбранных карбоксилсодержащих полисахаридов к структурообразованию в присутствии ионов $\mathrm{Ca}^{2+}$. С этой целью в индивидуальные $2 \%$ растворы полисахаридов вводили 0,005 моль/л сульфата кальция и после выдерживания в течение суток снимали для них кривые течения, представленные на рисунке 1 (кривые $\left.1^{\prime}-4^{\prime}\right)$. Из сравнения полученных кривых с аналогичными кривыми для исходных растворов можно сделать вывод, что значительному структурированию в присутствии ионов $\mathrm{Ca}^{2+}$ подвергаются лишь растворы альгината натрия, о чем свидетельствует резкое увеличение угла наклона кривой течения. Несколько увеличилась динамическая вязкость растворов пектина, без существенного изменения характера течения. Растворы же ГН и СХ не обнаружили признаков сшивающего действия на них ионов $\mathrm{Ca}^{2+}$.

Характер структурообразования в полимерных смесях в значительной степени определяется совместимостью полимерных компонентов [19, с. 26-144; 20]. О совместимости полимеров в общем растворителе 
можно судить по степени отклонения экспериментальной зависимости «вязкость - состав» от теоретической, полученной расчетом в предположении, что вязкость смеси является аддитивной величиной. При этом принято считать, что условию аддитивности отвечает прямая, соединяющая на диаграмме «состав свойство» ординаты, отвечающие величинам вязкости эквиконцентрированных растворов каждого из компонентов смеси. Для исследования совместимости альгината натрия с другими использованными полисахаридами готовили смеси с разным объемным соотношением исходных $2 \%$ растворов компонентов. При этом суммарная концентрация смешанного раствора по полимеру оставалась равной 2 масс.\% Полученные зависимости вязкости смесей от их состава представлены на рисунке 2, на котором пунктирные линии соответствуют аддитивным значениям. Наибольшая совместимость получена для смесей АН-ГН, для которых в значительном диапазоне составов наблюдается положительное отклонение вязкости от аддитивных величин. Этот факт может свидетельствовать в пользу образования лабильных гетероагрегатов. Однако в целом малая степень отклонений вязкостей смесей от аддитивных значений скорее свидетельствует об отсутствии между молекулами двух биополимеров значительных взаимодействий, которые бы могли привести к образованию интерполимерных комплексов.

Для смешанных растворов АН-СХ и АН-ВМП (рис. 2, кривые 1,2) получено существенное отрицательное отклонение значений динамической вязкости от аддитивных величин, что свидетельствует об ограниченной совместимости полимеров в водном растворе. Это, по-видимому, связано с тем, что эти полисахариды обладают более низким химическим сродством к АН по сравнению с ГН из-за высокого содержания метоксилированных звеньев в случае ВМП и присутствия крупных сукцинильных заместителей в случае СХ.

Следующим этапом работы было получение смешанных гидрогелей, характеризующихся пластической формосохраняемостью. Это достигалось введением в смешанные растворы ионов Са ${ }^{2+}$ в количестве 0,011 моль/л. Эта концентрация ионов кальция является достаточной для образования прочной трехмерной сетки геля в $2 \%$ растворе альгината с полной потерей текучести. Представляло интерес выяснить, в какой степени допустима частичная замена альгината каждым из выбранных полисахаридов, чтобы смесь сохраняла способность к образованию с ионами $\mathrm{Ca}^{2+}$ формоустойчивых гидрогелей. При этом следует учитывать, что, как было показано выше, вводимые полисахариды либо вообще не подвергаются трехмерной сшивке ионами кальция (ГН, СХ), либо эта способность выражена очень слабо (ВМП). Экспериментально было установлено, что такая замена при сохранении постоянной суммарной концентрации по полимерам (2 масс.\%) в достаточно широких пределах (от 40 до 60\%) не приводит к потере формуемости. Повидимому, образование кластеров альгинат-кальциевых комплексов индуцирует ассоциацию молекул второго полисахарида. Формоустойчивость в смесях обеспечивается за счет суммарного действия двух форм структурирования: химической (за счет образования хелатных комплексов между карбоксилатными анионами и катионами кальция) и физической (за счет межмолекулярных взаимодействий).

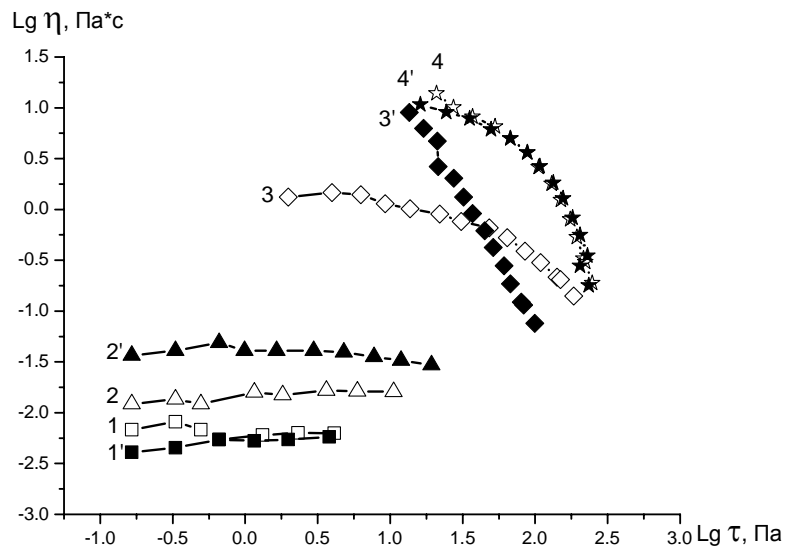

Рис. 1. Кривые течения 2\% растворов СX $\left(1,1^{\prime}\right)$, ВМП $\left(2,2^{\prime}\right)$, АН $\left(3,3^{\prime}\right)$ и ГН $\left(4,4^{\prime}\right)$, исходных (1-4) и содержащих 0,005 моль/л ионов $\mathrm{Ca}^{2+}\left(1^{\prime}-4^{\prime}\right)$

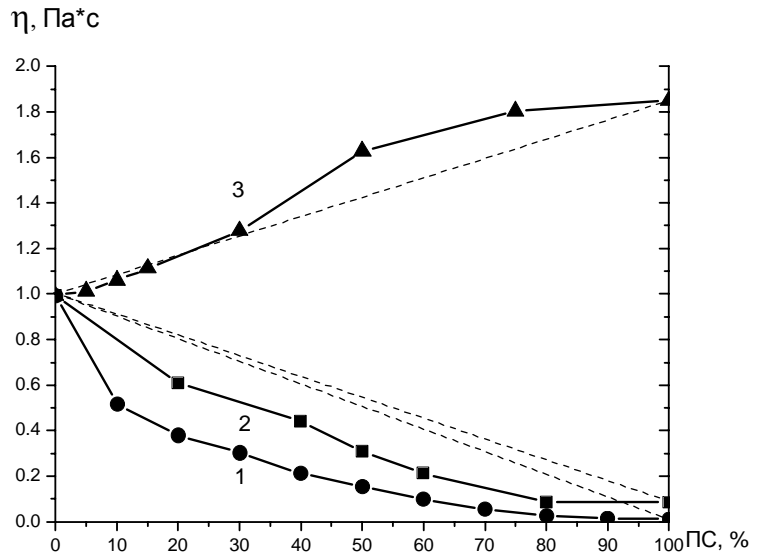

Рис. 2. Зависимость динамической вязкости $\eta$ от концентрации второго полисахарида ПС в смесях АН : CX (1), АН : ВМП (2), АН : ГН (3) при скорости сдвига $72,9 \mathrm{c}^{-1}$ 
Для проведения испытаний из смесей полисахаридов различного состава были сформованы образцы в виде одинаковых упругих дисков, для которых проводились серии экспериментов в одинаковых условиях для построения зависимостей «состав - свойство».

Полимерные гидрогели представляют собой гидрофильные, сшитые макромолекулярные системы, способные удерживать значительные количества воды, с сохранением при этом свойств, присущих твердым телам (определенная форма, механические модули, характеризующие свойства материала при вынужденных деформациях). Для исследования физико-механических характеристик образцы гидрогелей из смесей полисахаридов подвергали испытаниям путем сдавливающих деформаций. Полученные экспериментальные данные представлены на графиках «состав - свойство» (рис. 3а, б, в). Как следует из приведенных экспериментальных данных, упругость и деформируемость гидрогелей снижается при увеличении содержания второго полисахарида в смесях с альгинатом натрия. В случае ГН и ВМП это уменьшение происходит скачкообразно при их содержании в смешанных гидрогелях 30 и 40\% соответственно. При этой же концентрации скачкообразно в несколько раз увеличивается показатель липкости для этих образцов. Это свидетельствует о том, что часть макромолекул из-за недостаточной связанности сохраняет способность мигрировать из объема гидрогелевой матрицы к поверхности, контактирующей с прибором. Наименьшую прочность к механическим нагрузкам обнаружили образцы с ГН. Как было показано выше, именно ГН имеет наилучшую совместимость с АН (рис. 2), но при этом ГН не обладает собственной способностью сшиваться ионами $\mathrm{Ca}^{+2}$. По-видимому, благодаря хорошей совместимости при приготовлении смесей крупные макромолекулы ГН внедряются между макромолекулами АН. При последующем введении ионов кальция в смесь АН-ГН из-за стерических препятствий трехмерная сетка, образованная макромолекулами АН, оказывается более дефектной, чем в случае введения других, менее совместимых полисахаридов, имеющих меньший размер макроцепей.

Увеличение в смесях содержания СХ в наименьшей степени снижает формоустойчивость гидрогелевых образцов, причем снижение упругости в данном случае происходит не скачкообразно, а монотонно. Такой результат, возможно, объясняется участием сукцинильных карбоксильных групп в интерполимерном комплексообразовании с участием ионов $\mathrm{Ca}^{2+}$. На связанность макромолекул СХ в альгинатной матрице указывают также данные по липкости. В отличие от ГН и ВМП для этого полисахарида не наблюдается скачкообразного возрастания этого показателя с уменьшением доли альгината в смесях.

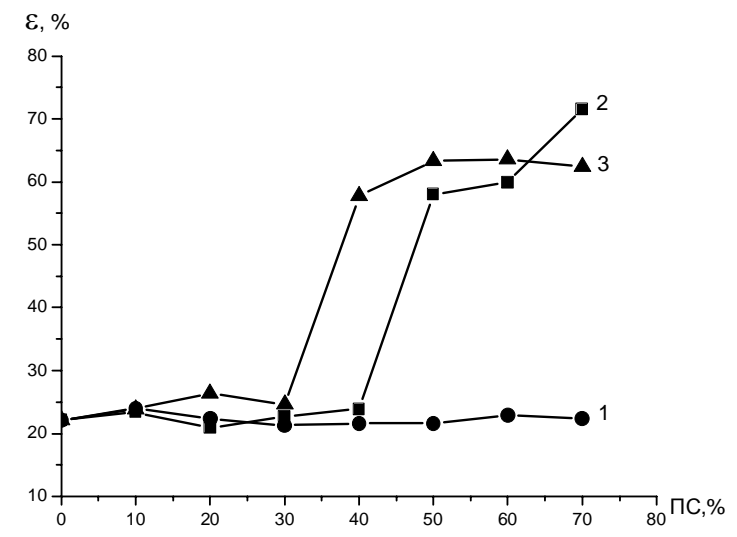

a)

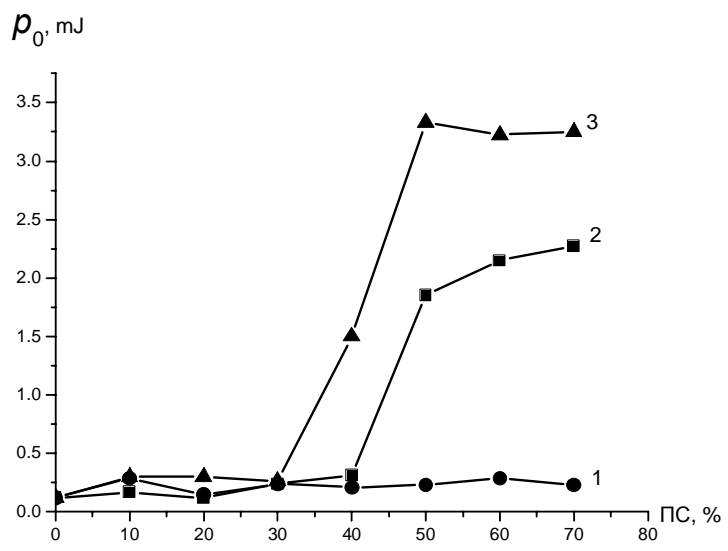

B)

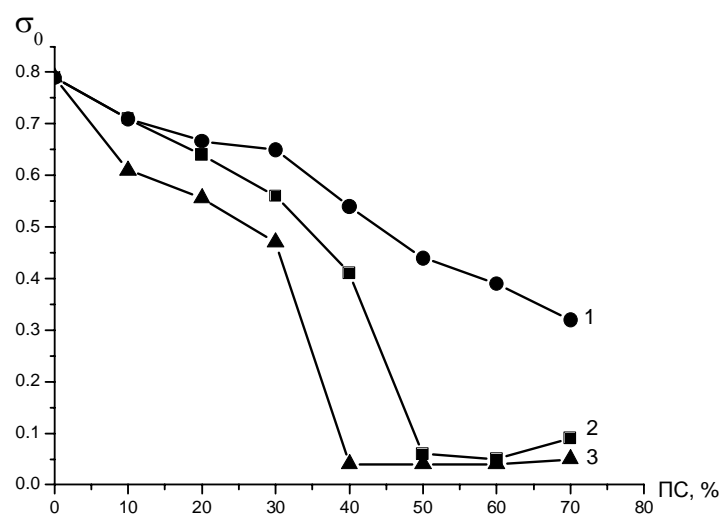

б)

Рис. 3. Влияние доли второго полисахарида ПС в смешанных формоустойчивых гидрогелях АН : CX (1), АН : ВМП (2), АН : ГН (3) на деформируемость $\varepsilon(\mathrm{a})$, упругость $\sigma_{0}$ (безразмерная величина) (б) и показатель липкости $\rho_{0}$ (в) 
Значительный практический и теоретический интерес представляет способность гидрогелей отделять воду при синерезисе или поглощать ее дополнительное количество при выдерживании в водной среде. Экспериментальные данные по зависимости этих характеристик от состава смешанных формоустойчивых гидрогелей представлены на рисунках 4 и 5.

При погружении в водную среду гидрогелевые диски за счет осмотических сил изотропно набухают, сохраняя свою целостность. На рисунке 4 представлены зависимости степени набухания гидрогелевых дисков от их полимерного состава для продолжительности выдерживания в воде 2 и 6 ч. Во всех случаях наблюдается существенное снижение степени набухания гидрогелей с увеличением доли вводимого в альгинатные гидрогели полисахарида. Следует отметить, что введение $20 \%$ ГН практически не изменяет этого показателя. В наибольшей степени снижение степени набухания с уменьшением содержания альгината в смесях наблюдается для СX.

Известно, что альгинатные гидрогели, трехмерно сшитые ионами кальция, способны к синерезису, т.е. к уплотнению, сопровождающемуся отделением водной среды. На рисунке 5 представлены экспериментальные данные по влиянию содержания второго компонента в смешанных гидрогелях на количество отделяемой воды. Как следует из представленных графиков, введение ГН не снижает устойчивости гидрогелей к синерезису, что согласуется с литературными данными о высокой водоудерживающей способности этого полисахарида [16]. Увеличение доли СХ и ВМП в смесях с АН существенно увеличивает склонность к синерезису, что ограничивает использование подобных смешанных гидрогелей в областях, для которых данный показатель является критическим.

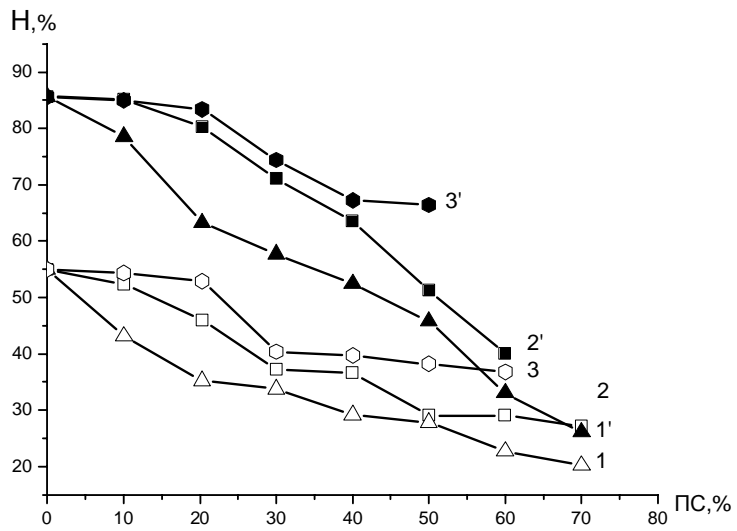

Рис. 4. Влияние доли второго полисахарида ПС в смешанных формоустойчивых гидрогелях $\mathrm{AH}$ : CX $\left(1,1^{\prime}\right)$, АН : ВМП $\left(2,2^{\prime}\right)$, АН : ГН $\left(3,3^{\prime}\right)$ на степень их набухания Н при выдерживании в воде 2 ч (1-3) и 6 ч $\left(1^{\prime}-3^{\prime}\right)\left(\mathrm{t}=24^{\circ} \mathrm{C}\right)$

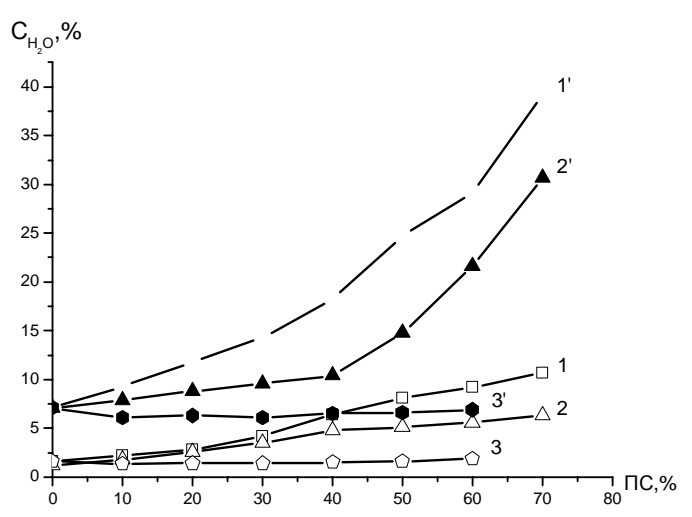

Рис. 5. Влияние доли второго полисахарида ПС в смешанных формоустойчивых гидрогелях $\mathrm{AH}: \mathrm{CX}\left(1,1^{\prime}\right), \mathrm{AH}: \mathrm{BM \Pi}\left(2,2^{\prime}\right), \mathrm{AH}:$ ГН $\left(3,3^{\prime}\right)$ на количество воды $C_{\mathrm{H}_{2} \mathrm{O}}$, выделившееся при синерезисе за 1 сутки (1-3) и за 6 суток $\left(1^{\prime}-3^{\prime}\right)$

\section{Выводы}

1. Получены формоустойчивые трехмерно сшитые ионами кальция гидрогели на основе альгината натрия и его смесей с карбоксилсодержащими полисахаридами, не обладающими собственной способностью сшиваться ионами кальция: гиалуронатом натрия, высокометоксилированным пектином и сукцинилированным хитозаном.

2. Установлено, что с увеличением содержания второго полисахарида в смесях с альгинатом снижается степень набухания гидрогелей в воде и их устойчивость к синерезису.

3. Физико-механические характеристики гидрогелей с увеличением содержания второго полисахарида в смесях с альгинатом уменьшаются в случае СХ монотонно и несущественно, а в случае ГН и ВМП скачкообразно при превышении их критических концентраций в смесях 40 и 50\% соответственно. 


\section{Список литературы}

1. Х Хотимченко Ю.С., Ковалев В.В., Савченко О.В., Зиганшина О.А. Физико-химические свойства, физиологическая активность и применение альгинатов - полисахаридов бурых водорослей // Биология моря. 2001. Т. 27. №3. С. 151-162.

2. Усов А.И. Альгиновые кислоты и альгинаты: методы анализа, определения состава и установления строения // Успехи химии. 1999. Т. 68. Вып. 11. С. 1051-1061.

3. Grant G. T., Morris D. A., Rees P.J.P., Smith K.A. Biological interactions between Polysaccharides and divalent cations: The eggbox model // Febs letters. Amsterdam. 1973. Vol. 32. N1. Pp. 195-198.

4. Щипунов Ю.А., Конева Е.Л., Постнова И.В. Гомогенные гели альгината: фазовое поведение и реологические свойства // Высокомолекулярные соединения. 2002. Сер. А. Т. 44. №7. С. 1201-1211.

5. Vincent J. Structural biomaterials. Princeton. 1990. Pp. 247.

6. Skjak-Braek G., Espevik T. Application of alginate gels in biotechnology and biomedicine // Carbohydr. Eur. 1996. Vol. 14. N19. Pp. 237-242.

7. Kshirsagar N.A. Drug delivery systems // Indian Journal of Pharmacology. 2000. N32. Pp. 54-61.

8. Pandey R., Khuller G.K. Chemotherapeutic potential of alginate-chitosan microspheres as anti-tubercular drug carriers // Journal Antimicrobial. Chemotherapy. 2004. Vol. 53. N4. Pp. 635-640.

9. Олтаржевская Н.Д., Коровина М.А., Савилова Л.Б. Перевязочные материалы с пролонгированным лечебным действием // Российский химический журнал. 2002. T. XLVI. №1. С. 133-141.

10. Добродеева Л.К., Белозеров В.П., Кондаков Н.И., Цимбаленко Н.В., Шилина Л.П., Добродеев К.Г. Пищевые добавки водорослевого происхождения для профилактики и лечения иммунодефицитных состояний. Архангельск, 1996. 12 с.

11. da Silva M.A., Bierhalz A.C.K., Kieckbusch T.G. Alginate and pectin composite films crosslinked with $\mathrm{Ca}^{2+}$ ions: Effect of the plasticizer concentration // Carbohydrate Polymers. 2009. Vol. 77. PP. 736-742.

12. Донченко Л. В. Технология пектина и пектинопродуктов. М., 2000. С. 255.

13. Мухамеджанова М.Ю., Филатова А.В., Джурабаев Д., Тураев А.С. Процессы гелеобразования и реологические свойства умеренно-концентрированных водных растворов цитрусового пектина в присутствии ионов поливалентных металлов // Химия растительного сырья. 2012. №1. С. 51-60.

14. Thibault J.F., Rinaudo M. Chain association of pectic molecules during calcium induced gelation // Biopolymers. 1986. Vol. 25. Pp. 455-468.

15. Kartel M.T., Kupchik L.A., Veisov B.K. Evaluation of pectin binding of heavy metal ions in aqueous solutions // Chemosphere. 1999. Vol. 38. N11. Pp. 2591-2596.

16. Хабаров В.Н., Бойков П.Я., Селянин М.А. Гиалуроновая кислота: получение, свойства, применение в биологии и медицине. М., 2012. С. 224.

17. Хитин и хитозан: Получение, свойства и применение / под ред. К.Г. Скрябина, Г.А. Вихоревой, В.П. Варламова. М., 2002. С. 160.

18. Ильина А.В., Зубарева А.А., Курек Д.В., Левов А.Н., Варламов В.П. Наночастицы на основе сукцинилированного хитозана с доксорубицином: формирование и свойства // Российские нанотехнологии. 2012. Т. 7. №1-2. C. $84-89$.

19. Краузе С. Совместимость в системах полимер-полимер // Полимерные смеси : под ред. Пола Д., Ньюмена С. M., 1981. T. $1.552 \mathrm{c}$.

20. Кулезнев В.Н. Ассоциация макромолекул и ее влияние на взаимную растворимость полимеров // Высокомолекулярные соединения. 1993. Т. 35. №8. С. 1391-1402. 
Yusova A.A. ${ }^{l}$, Gusev I.V. ${ }^{2}$, Lipatova I.M. ${ }^{{ }^{*}}$ PROPERTIES OF THE HYDROGELS BASED ON A MIXTURE OF SODIUM ALGINATE WITH OTHER POLYSACCHARIDES OF NATURAL ORIGIN

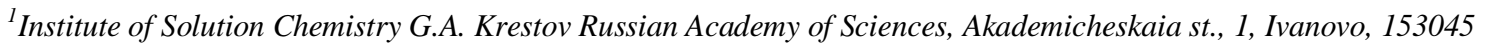

(Russia),e-mail: aay@isc-ras.ru

${ }^{2}$ Moscow State University of Technology and management K.G. Razumovsky, Zemlianoi Val st., 73, Moscow, 109004

(Russia), e-mail: igor.gusev.1986@mail.ru

The form stable calcium alginate hydrogels in which sodium alginate has partially replaced by carboxyl containing polysaccharides that has no own ability to cross-linking by means of calcium ions have obtained. Sodium hyaluronate, high methoxyl pectin and succinylchitosan were used as the second polysaccharide. Experimental data on the influence of the second polysaccharide in the mixtures with the sodium alginate on the extent of swelling of hydrogels in water, resistance to syneresis, and physico - mechanical characteristics are discussed for the different mixed hydrogels compositions.

Keywords: sodium alginate, succinylchitosan, high methoxyl pectin, sodium hyaluronate, ionotropic gelation by ions calcium, the physico-mechanical properties of the mixed hydrogels.

\section{References}

1. Hotimchenko Ju.S., Kovalev V.V., Savchenko O.V., Ziganshina O.A. Biologija morja, 2001, vol. 27, no. 3, pp. 151162. (in Russ.)

2. Usov A.I. Uspehi himii, 1999, vol. 68, issue 11, pp. 1051-1061. (in Russ.)

3. Grant G. T., Morris D. A., Rees P.J.P., Smith K.A. Febs letters. Amsterdam, 1973, vol. 32, no. 1, pp. 195-198.

4. Shhipunov Ju.A., Koneva E.L., Postnova I.V. Vysokomolekuljarnye soedinenija, 2002, ser. A, vol. 44, no. 7. pp. 1201-1211. (in Russ.)

5. Vincent J. Structural biomaterials. Princeton. 1990. P. 247.

6. Skjak-Braek G., Espevik T. Carbohydr. Eur, 1996, vol. 14, no. 19, pp. 237-242.

7. Kshirsagar N.A. Indian Journal of Pharmacology, 2000, no. 32, pp. 54-61.

8. Pandey R., Khuller G.K. Journal Antimicrobial. Chemotherapy, 2004, vol. 53. no. 4, pp. 635-640.

9. Oltarzhevskaja N.D., Korovina M.A., Savilova L.B. Rossijskij himicheskij zhurnal, 2002, vol. XLVI, no. 1, pp. $133-141$.

10. Dobrodeeva L.K., Belozerov V.P., Kondakov N.I., Cimbalenko N.V., Shilina L.P., Dobrodeev K.G. Pishhevye dobavki vodoroslevogo proishozhdenija dlja profilaktiki i lechenija immunodificitnyh sostojanij. [Nutritional supplements algal origin for the prevention and treatment of immunocompromised states]. Arhangel'sk, 1996, 12 p. (in Russ.)

11. da Silva M.A., Bierhalz A.C. K., Kieckbusch T.G. Carbohydrate Polymers, 2009, vol. 77, pp. 736-742.

12. Donchenko L. V. Tehnologija pektina i pektinoproduktov. [Technology of pectin and pectin]. Moscow, 2000, pp. 255.

13. Muhamedzhanova M.Ju., Filatova A.V., Dzhurabaev D., Turaev A.S. Himija rastitel'nogo syr'ja, 2012, no. 1, pp. 51-60. (in Russ.).

14. Thibault J.F., Rinaudo M. Biopolymers, 1986, vol. 25, pp. 455-468.

15. Kartel M.T., Kupchik L.A., Veisov B.K. Chemosphere, 1999, vol. 38, no. 11, pp. 2591-2596.

16. Habarov V.N., Bojkov P.Ja., Seljanin M.A. Gialuronovaja kislota: poluchenie, svojstva, primenenie v biologii i medicine. [Hyaluronic acid: Preparation, properties and application in Biology and Medicine]. Moscow, 2012, pp. 224. (in Russ.)

17. Hitin i hitozan: Poluchenie, svojstva i primenenie / ed. K.G. Skrjabina, G.A. Vihorevoj, V.P. Varlamova. [Chitin and chitosan: Preparation, Properties and Applications]. Moscow, 2002, pp. 160. (in Russ.)

18. Il'ina A.V., Zubareva A.A., Kurek D.V., Levov A.N., Varlamov V.P. Rossijskie nanotehnologii, 2012, vol. 7, no. 1-2, pp. 84-89.

19. Krauze S. Sovmestimost'v sistemah polimer-polimer. V kn.: Polimernye smesi / ed. Pola D., N'jumena S. [Compatibility in polymer-polymer. In: Polymer blends]. vol. 1, Moscow, 1981, pp. 552. (in Russ.)

20. Kuleznev V.N. Vysokomolekuljarnye soedinenija, 1993, vol. 35, no. 8, pp. 1391-1402. (in Russ.)

Received May 13, 2014

*Corresponding author. 